International Journal of Biology, Pharmacy and Allied Sciences (IJBPAS)

'A Bridge Betueen Caboratory and QRendo'

WWW.ijbpas.com

\title{
A REVIEW ON CHARACTERIZATION OF MICROORGANISMS FROM INDUSTRIAL WASTEWATER
}

\section{KUBAVAT $R^{1}$, UPADHAYAY ${ }^{2}$, ANDHARE $P^{2}$ AND PRAJAPATI $P^{2 *}$}

1: Parul Institute of Applied Science, Parul University, PO- Limbda, TA- Waghodia, Di- Vadodara, 391760

2: Assistant Professor, Department of Microbiology, Parul Institute of Applied Science, Parul University, PO- Limbda, TA- Waghodia, Di- Vadodara, 391760

*Corresponding Author: Dr. Priyanka Prajapati; E Mail: priyanka.mistry82141@paruluniversity.ac.in;

Tel: +919913562946

Received 24 ${ }^{\text {th }}$ Jan. 2021; Revised $27^{\text {th }}$ Feb. 2021; Accepted $28^{\text {th }}$ March 2021; Available online $1^{\text {st }}$ April 2021

\section{https://doi.org/10.31032/IJBPAS/2021/10.4.1052}

\section{ABSTRACT}

Industrial wastewater, especially that from chemical and pharmaceutical manufacturing, often contains substances that must be processed before being discharged into a biological treatment plant and then into the surrounding water bodies. The flow and emission strength of industrial wastewater vary dramatically. As a result, assigning fixed values to their voters is impossible. In general, suspended, colloidal, and dissolved solids can be found in industrial wastewaters. They can also be excessively acidic or alkaline, as well as contain high or low levels of coloured matter.Microbial diversity and their ability to degrade particular contaminants determine the effectiveness of a biological wastewater treatment system. Physical, chemical and biological factors all play a role in the application of wastewater treatment technologies. In wastewater treatment plants, microorganisms play a significant role in the degradation and elimination of organic waste and xenobiotic contaminants. To process effluents high in fats and oils, some microorganisms have been used in complementary therapies.

Keywords: Industrial wastewater, Isolation, Test organisms (E. coli, Bacillus Subtilis), Biochemical activity 


\section{INTRODUCTION}

Any water that has been polluted by human activity is considered wastewater. "wastewater is a by-product of residential, manufacturing, commercial or agricultural activities" according to the EPA (Environmental Protection Agency). The characteristics of waste water vary depending on the source [1]. Domestic wastewater, urban wastewater from cities, and industrial wastewater are all examples of wastewater. Wastewater can contain physical, chemical and biological pollutants [1]. Flush toilets, sinks, dishwashers, washing machines, bath tubs and showers can all contains wastewater in the home. As compared to flush toilets, household that use dry toilets produce less wastewater. Water is an inevitable part of the daily routine of almost all living beings [2]. During recent years, most parts of the earth have begun to face severe water scarcity and there is a need to adapt the methods for reuse of wastewater [2]. Pharmaceutical wastewater is a complex mixture of different organic and inorganic compounds including residues of active pharmaceutical substances, solvents, toxic and chemicals that inhibit microbial activity of the activated sludge process.

A sanitary sewage system that only transports waste could be used to convey wastewater. Alternatively, wastewater can be routed into a hybrid sewer system, which transport both stormwater runoff and sewage, as well as likely industrial wastewater. Treated wastewater is discharged to a receiving water body after treatment at a wastewater treatment facility. If the treated waste is used for another reason, the terms "WASTEWATER REUSE" and "WATER RECLAMATION" apply.Water pollution can occur when wastewater is discharged into the atmosphere without being properly handled.The effluent of the pharmaceutical industry is normally composed of wastewater from the production lines, waste from production and leftovers of substances removed from machinery and equipment. It has specific characteristics that can vary depending on the products that are manufactured by the industrial unit [3]. The effluent from the manufacture of antibiotics which contain residues of the active ingredient. To avoid being taken into environment, this residue must first go through a process of inactivation or removal of the active principle. Pharmaceutical industrial effluents can be treated using a number of methods [4]. Industrial wastewater, or water used to produce commercial goods in virtually all phases of production in all sectors, is one of the most important by-products of industrial or commercial activities. Once this process water has been used, it is 
considered waste and needs to be treated before it is discharged [5]. Industrial waste water is not just a by-product of oil and gas or chemical manufacturing companies, but also a by-product of food and beverage processing industries.Until wastewater can be safely discharged to ground into bodies of water, of reused in plant operations, organic matter, metals, and other pollutants must be extracted [6].

\section{TYPES OF INDUSTRIAL WASTEWATER}

Inorganic industrial wastewater is primarily generated in the coal and steel industries, non-metallic minerals industries, and commercial enterprises and industries that conduct metal surface processing.These wastewaters contain a high percentage of suspended matter, which can be removed by sedimentation, which is often combined with chemical flocculation using iron or aluminum salts and organic polymers.

Water is used to move and separate coal from dead rock, and this water, which includes significant quantities of coal and rock particles, is referred to as coal washing water. After the coal and rock particles have been removed through flotation and sedimentation, the coal-washing water is recycled.In certain cases, wastewater is generated along with solids and oils, and it often contains extremely harmful solutes. Small and medium-sized non-metallic minerals and metal manufacturing plants are located in such a way that their wastewater is discharged into municipal wastewater systems, and they must treat or purify their effluent before discharged in order to comply with local regulations.

Mineral oil is present in other wastewater from rolling mills, and additional installations, such as scum boards and skim-off apparatus, are needed for the preservation and removal of mineral oils. Residues of emulsified oil remaining in the water also need chemical flocculation [7].

Organic industrial wastewater is a byproduct of chemical industries and largescale chemical plants that primarily use organic substance in their chemical reactions. Natural substances with different origins and properties are found in the effluents. These can only be removed by special pre-treatment of the wastewater, followed by biological treatment [7].

Aerobic and Anaerobic wastewater

\section{treatment}

Anaerobic means "without air" while aerobic means "with air (oxygen)". The type of bacteria or microorganisms involved in the degradation of organic impurities in a given wastewater, as well as the operating conditions of the bioreactors, are closely related to these two concepts. As a result, aerobic treatment methods use microorganism to assimilate organic impurities by converting them to carbon dioxide, water, and biomass using molecular/free oxygen in the presence of 
air. Anthropogenic sources such as household and agricultural waste, as well as industrial processes, pollute many waters supplies today. The public's concern about the environmental consequences of wastewater pollution has grown. Several conventional wastewater treatment techniques, i.e., chemical coagulation, adsorption, activated sludge, have been applied to remove the pollution, however there are still some limitations, especially that of high operation costs [8]. The use of aerobic waste water treatment as a reductive medium is receiving increased interest due to its low operation and maintenance cost [9]. It's also simple to acquire, with strong efficacy and the ability to degrade pollutants. The use of waste water treatment technologies to extract contaminants from wastewater, such as halogenated hydrocarbon compounds, heavy metals, dyes, pesticides, and herbicides, which are the most common pollutants in wastewater, is discussed in this paper [9-10]. A constant supply of clean water is needed for the establishment and maintenance of a wide range of human activities [11]. Aquatic life and irrigation for agricultural production provide useful food from water supplies. However, most water supplies around the world are polluted by liquid and solid wastes created by human settlements and industrial activities [12]. The method of extracting physical, chemical, and microbiological pollutants from any form of wastewater, such as urban, commercial, or industrial wastewater, with the goal of creating a final effluent of a quality appropriate for either disposal or reuse, is known as wastewater treatment [13]. Various procedures are used to do this, depending on the treatment's primary goal. A wastewater treatment plant is made up of different treatment units that correspond to different wastewater treatment levels, as follows: I preliminary treatment, which eliminates coarse solids including floatables, grit, and grease; (ii) main treatment, which removes suspended solids and particulate organic matter; (iii) secondary (or biological) treatment, which removes biodegradable organic mettle. Although some modern treatment technologies are more efficient at eliminating pathogens, it has been suggested that in most cases they would not be a cost-effective alternative to traditional WWTP [14]. MBR systems are becoming more cost-effective due to lower membrane costs, but they are still a relatively "energyintensive" operation.Wastewater is classified as a liquid waste discharged by residential commercial, industrial, and agricultural properties, and it may contain a variety of pollutants and concentration. Water is one of the most vital elements on the planet. Both plants and animals need water in order to survive. There would be 
no life on Earth without water. It occupies approximately $71 \%$ of the Earth's surface [15].

Prior to the late $1800 \mathrm{~s}$, the most popular form of human waste disposal was to use an outdoor privy, with the majority of the population defecating in the open. Sewage treatment plants have been built in cities after Louis Pasteur and other scientists demonstrated that sewage-borne bacteria were responsible for many infectious diseases [16].

Waste treatment attempts in the early 1900s were normally purchased wide field sand was used to disperse the water over the land, where it decayed due to microorganism action [17]. The amount of information available on sanitation, drainage, hazardous waste, and other topics is growing all the time. The first annual review published 122 articles for the twoyear period of 1932-33. The number of papers read every year had increased to 232 after ten years. Over the war years, the number of publications remained relatively constant, increasing to 287 in 1948 and 398 references for this 18th annual review. The most recent increases are almost entirely due to a resurgence in interest in hazardous waste. Industrialization has brought with it a slew of benefits and drawbacks. The production of waste is one of the negative effects of industrialization [18]. Industrial waste may be solid, gaseous, or liquid, with different management and treatment methods for each. Industrial waste management covers all forms of waste produced by industries, including industrial, biological, and household waste, and includes waste generated before, during, and after processing, as well as waste generated by customers. Industrial waste can, in some cases, be harmful to human health [17-18]. Human operation, such as the mining and processing of raw materials, produces waste in general. Industrial waste management encompasses all types of waste created by businesses, including industrial, biological, and household waste, as well as waste generated by consumers before, during, and after processing. In certain cases, industrial waste can be detrimental to human health. Human activity causes waste in general, such as mining and processing raw materials. A massive amount of industrial wastewater was discharged into rivers, streams, and coastal areas over the last century. This resulted in severe water contamination concerns, as well as harmful implications for the eco-system and human life. Industrial wastewater, or the water used to produce commercial goods in all sectors in virtually all stages of processing, is one of the most important byproducts of industrial or commercial activities. This process water is considered waste after it 
has been used and must be cleaned before being discharged [18].

\section{CHARACTERIZATION OF BACTERIA} IN INDUSTRIAL WASTEWATER

Bio-material in water supplies the microorganisms as food. These microorganisms oxidize waste, which needs to be supplied with oxygen. When supplied with plenty of nutrients, bacteria grow enormously rapidly. Some colonies may be coloured, some colonies may have circular shape and others are irregular. The colony characteristics are called morphology shape, size, pigmentation, etc.

There are several different types of bacteria (E.coli, Bacillus subtilis) that are found in nature and are closely related to humans. Humans have discovered a number of beneficial bacteria. However, there are numerous harmful bacteria in human living environments that pollute the air, water, soil, and food, posing a serious threat to human health. There are many bacteria in wastewater, and water contamination caused by wastewater discharge can spread numerous bacteria, including human pathogenic bacteria, posing a threat to human health and ecological protection [19].

E.coli is present in industrial wastewater. Escherichia coli are in the family Enterobacteriaceae. The bacteria are gram negative, rod shaped, non-spore forming, motile with flagella or nonmotile. They can grow under aerobic and anaerobic conditions and do not produce enterotoxins [20].

Escherichia coli are bacteria foundin the environment, food, and intestines of people and animals. E. coli are a large and diverse group of bacteria. Although most strains of E. coli are harmless, others can make you sick. Some kinds of $E$. coli can cause diarrhea, while others can urinary tract infections, respiratory illness and pneumonia, and others illnesses [21].

Bacillus subtilis bacteria have rigid cell walls composed of a thick peptidoglycan called murein. This rigidity helps to maintain the rod shape of the cell and can withstand high intracellular pressure [22] Bacillus subtilis is a Gram-positive bacterium, found in soil and the gastrointestinal tract of ruminants and humans. B. subtilis has been classified as a facultative anaerobe. B. subtilis cells are typically rod-shaped, and are about 4-10 micrometer long and 0.25-1.0 micrometer in diameter [23].

\section{CONCLUSION}

There are different bacteria are present in industrial wastewater. Bacteria are present with their different shape, size, margin. Bacteria can survive in that critical condition too. The bacteria are present indifferent industrial wastewater includes Acinetobacter, Bacillus, Flavobacterium, Micrococcus and 
Pseudomonas etc. These bacteria are useful and harmful too for human health.

\section{ACKNOWLDGEMENT}

It's our privilege and honour to express our sincerest gratitude to the Parul University, Vadodara, Gujarat for providing me all the necessary support and facilities including state of the art infrastructural facilities with advanced technological scientific laboratories and everything else that was required to carry out this work.

\section{REFERENCES}

[1] ShuD., HeY. et al: Microbial structures and community functions of anaerobic sludge in six full-scale wastewater treatment plants as revealed by 454 high-throughput pyrosequencing. Bioresource Technology. June2015; 186: 163-172.

[2] Cooper, K.E: Theory of antibiotic inhibition zones in agar media. Nature.Sept 1995; 176 (4480): 510511.

[3] ESPINOSA, A. C., Aris C.S et al: Comparative study of enteric viruses, coliphages and indicator bacteria for evaluating water quality in a tropical high-altitude system. Environmental Health; Oct 2009; 8 (49): 1-10.

[4] Al-HindiR. R., Al-Najada A.R et al: Isolation and identification of some fruit spoilage fungi: Screening of plant cell wall degrading enzymes. African Journal of Microbiology Research. Feb 2011; 5(4): 443-448.
[5] Hopkins J.N. et al: The Cloaca Maxima and the monumental manipulation of water in archaic Rome. Waters Rom. March 2007; 4: 1-15.

[6] GRABOW W. O. K: Bacteriophages: Update on application as models for viruses in water. Water Sa. April 2001; 27 (2): 251-268.

[7] Bouki C., Venieri D et al: Detection and fate of antibiotic resistant bacteria in wastewater treatment plants: a review. Ecotoxicol. Environ. Saf. May 2013; 91: 1-9.

[8] Jones H.W: Report of a series of cases of syphilis treated by Ehrlich's arsenobenzol at the Walter Reed General Hospital, District of Columbia. Boston Med. Surg. J. March1911; 164(11): 381-383.

[9] Kalesse M., Böhm A. et al: Synthesis of Antibiotics, How to Overcome the Antibiotic Crisis. Springer. 2016; 419445.

[10] Lee L.-H., Chan K.-G. et al: The search for biological active agent (s) from actinobacteria. Front. Microbiol. May 2018; 9: 824.

[11] Moges, F., Endris, M. et al: Isolation and characterization of multiple drug resistance bacterial pathogens from waste water in hospital and nonhospital environment, Northwest Ethiopia. BMC Research Notes. April 2014; 7: 215.

[12] Orias F., Perrodin Y: Characterisation of the ecotoxicity of hospital effluents; 
a review. Sci. Total Environ. June 2013; 454-455: 250-276.

[13] Pacarynuk, L.A. et al: Biochemical Tests. In: Principles of Microbiology, Laboratory Manual, Spring, TX, USA; 2004; 28-34.

[14] Risebrough R. et al: Conservation biology; fatalmedicinefor vultures. Nature. Feb 2004; 427(6975): 596-8.

[15] Rayan, C.G. et al: Sherris Medical Microbiology, (4 ${ }^{\text {th }}$ ed). McGraw Hills, ISSN; 2004; 08385-8529-9.

[16] Sharpe, M. et al: High on pollution: drug as environmental contaminants. Journal of Environmental Monitoring.Jun 2003; 5(3): 43-46.

[17] USEPA et al; Review of coliphages as possible indicators of fecal contamination for ambient water quality. Office of Water, Washington, DC. $2015 ; 820-\mathrm{R}-15-098$.

[18] Vane J.R.\& Botting R.M:Antiinflammatory drugs and their mechanism of action. Inflamm; Res. Oct 1998; 47: 78-87.

[19] Watkinson A.J., Murby E.J. et al; The occurrence of antibiotics in an urban watershed: from wastewater to drinking water. Sci. Total Environ. April 2009; 407(8): 2711-2723.

[20] Nataro S. Et al; Escherichia, Shigella and Salmonella; Manual of clinical microbiology. Washington, DC, USA; ASM press. $2007 ; 9^{\text {th }}$ ed: $670-687$.

[21] Boatwright, Janda, J. M. et al; Enterobacteriaceae: Introduction and Identification. Washington, DC: ASM press; Manual of clinical Microbiology 2007; $9^{\text {th }}$ ed.; 649-669.

[22] Dubnau DA. et al; The Molecular Biology of the Bacilli. Bacillus subtilis. New York, Academic Press. 2012; 1.

[23] Ambrosiano N. et al; "Lab bioreactor tests to be safe, public to be well informed". Los Alamos National Labs. September 2008. 